\title{
Moet Abraham sy kind offer? 'n Etiese beoordeling
}

\author{
Author: \\ Henk Stoker ${ }^{1}$ \\ Affiliation: \\ ${ }^{1}$ Faculty of Theology, \\ North-West University, \\ Potchefstroom Campus, \\ South Africa \\ Correspondence to: \\ Henk Stoker \\ Email: \\ henk.stoker@nwu.ac.za \\ Postal address: \\ Private Bag X6001, \\ Potchefstroom 2520, \\ South Africa \\ Dates: \\ Received: 06 Sept. 2013 \\ Accepted: 05 Mar. 2014 \\ Published: 20 Aug. 2014 \\ How to cite this article: \\ Stoker, H., 2014, 'Moet \\ Abraham sy kind offer? 'n \\ Etiese beoordeling', In die \\ Skriflig 48(2), Art. \#1724, \\ 8 pages. http://dx.doi. \\ org/10.4102/ids.v48i2.1724

\section{Copyright:} \\ (C) 2014. The Authors. \\ Licensee: AOSIS \\ OpenJournals. This work \\ is licensed under the \\ Creative Commons \\ Attribution License.
}

Read online:
In Genesis 22 gee die God van die Bybel aan Abraham die opdrag om sy kind te offer. Abraham aanvaar die opdrag sonder om vir sy seun in te tree. Sy optrede - so anders as sy vorige optrede in belang van mense - kan net verstaan word teen die agtergrond van God se belofte van 'n groot en geseënde nageslag deur hierdie seun. Abraham moes besef het dat dit 'n toets vir sy vertroue in die belofte en almag van God was. Die feit dat Abraham se aanvaarding van die opdrag nie net as eties korrek beskryf kan word nie, maar volgens die Bybel ook as 'n geloofsdaad gesien moet word, word indringend bespreek. Die etiese beoordeling vind onder andere plaas na aanleiding van die normatiwiteit van lewe, die beginsels van liefde en gehoorsaamheid, ontsag vir God, en 'n deontologiese beoordeling volgens die motief, doel, middel en gevolg.

Did Abraham have to sacrifice his child? An ethical assessment. In Genesis 22 the God of the Bible commanded Abraham to sacrifice his child. Abraham accepted the command without interceding for his son. His actions - so different from his previous actions on behalf of people - can only be understood against the backdrop of God's promise of many and blessed descendants through this son. Abraham would have realised that it was a test for his faith in the promise and omnipotence of God. The fact that Abraham's acceptance of the assignment can not only be described as ethically just, but also be seen in accordance to the Bible, as an act of faith, are discussed in depth. The ethical assessment takes place, amongst others, according to the normativity of life, the principles of love and obedience, reverence for God, and an assessment of motive, aim, means and effect.

\section{Inleidend}

In Genesis 22:2 is 'n opdrag wat vir enige regdenkende mens verskriklik klink:

Vat jou seun, jou enigste seun, Isak wat jy liefhet, en gaan na die landstreek Moria toe en offer jou seun as brandoffer daar op een van die berge wat ek vir jou sal aanwys.

Iemand wat vandag sou poog om so 'n opdrag te gehoorsaam, sou van moord of ten minste poging tot moord aangekla word. Die optrede sou as verregaande en immoreel beskryf word. Tog vertel Genesis 22 dat Abraham wel gegaan het om hierdie opdrag uit te voer en boonop lees ons geen veroordeling van sy optrede in hierdie hoofstuk of in die res van die Bybel nie.

Hierdie artikel soek antwoorde op die etiese verantwoordbaarheid van Abraham se optrede in sy spesifieke omstandighede. Sou dit byvoorbeeld vandag as etiese motivering gebruik kan word vir die doodmaak van mense - ook vir die ongeborenes deur aborsie? Moet Siebert (2009:212) se voorbeeld dalk eerder gevolg word om uit hierdie etiese dilemma te kom? Siebert volg naamlik 'n tweeledige hermeneutiek waarin 'n mens slegs die dele in die teks aanvaar wat vir jou in die Christelike etiek aanvaarbaar is, terwyl jy daardie dele van die verhaal wat teen die Christelike norme ingaan, as vals verwerp. As teoretiese vertrekpunt word geneem dat die optrede van Abraham soos dit in Genesis 22 verhaal word, in sy spesifieke konteks nie as immoreel gesien hoef te word of as 'n optrede wat teen die Christelike etiek indruis nie. Dit hou onder andere in dat dit ' $n$ verdraaiing van die Skrif sou wees om die optrede van Abraham en die verwysings in die Skrif daarna, as normatiewe grond voor te hou vir die doodmaak van kinders (of enige mens), alreeds gebore of nog ongebore.

\section{Skrifbeskouing en Genesis 22}

Terwyl die Christelike etiek meestal aborsie as die doodmaak van ongebore kinders beskou en dit daarom teenstaan (Geisler \& Snuffer 2007:115-122), vertel Genesis 22 hoe Abraham, die vader van alle gelowiges volgens die Christelike Nuwe Testament (Gal 3:7, 29), spesifiek gaan om sy gebore kind dood te maak. 
Curzer (2002:234) beskryf Abraham se bereidheid om sy kind te offer, net soos dié van Agamemnon wat sy kind offer in die verhaal van die stryd om Troje, as 'bewonderingswaardig immoreel'. Hoewel verstaanbaar, oorskry sowel Abraham as Agamemnon die moreel aanvaarbare. Volgens Curzer moes Abraham geweier het om hierdie opdrag uit te voer.

Hierteenoor staan diegene wat Abraham se optrede in so 'n mate as moreel geregverdig beskou het, dat hulle dit as 'n navolgenswaardige voorbeeld beskou het. Abraham se bereidheid tot die uitvoering van die opdrag om sy kind te offer, is in die Middeleeue gebruik om mense tot die oortuiging te bring dat kinderoffers toelaatbaar en selfs ' $n$ deug was. Simms (2000:360) beskryf hoe die Ashkenaz Jode in die elfde en twaalfde eeu na Christus, die verhaal van Abraham se offer van Isak verander het om by hulle besluit in te pas om hulle kinders te offer. Die Joodse gemeenskappe het die verhaal selfs gewysig, naamlik dat Abraham wel sy seun doodgemaak het - selfs drie keer - soos dit in kommentare en liedere destyds beskryf is. Volgens hulle leerstellings aanvaar God die offer van kinders wat in navolging van Abraham gedoen is.

Kaiser (1988:53-54) wys daarop dat dit nie God se bedoeling was dat Abraham die opdrag om sy seun te offer, moes uitvoer nie. God wat lewe gee, sou wel die reg hê om dit te neem, maar Hy verbied die doodmaak van mense - en spesifiek ook kinders en kinderoffers - op verskeie ander plekke in die $\mathrm{Ou}$ Testament (vgl. ook Kaiser 1983:262). Die doel van hierdie artikel is egter nie om op die rede en moraliteit van God se opdrag in te gaan nie, maar wel op die optrede van Abraham om uitvoering aan God se bevel te gee. ${ }^{1}$

Dit wat in Genesis 22 oor die optrede van Abraham in opdrag van God staan, word in Genesis as historiese gebeure weergegee en daar word ook later in die Bybel daarna verwys as historiese gebeure (vgl. Heb 11:17-19). Hierdie artikel beskou dus die hoofstuk en die geskiedenis as werklike gebeure (Young 1964:ii). Kaiser (2001:84-96) wy 'n hele hoofstuk daaraan om te wys dat buite-bybelse getuienis ook daarop dui dat die verhale oor die aartsvaders historiese gebeure is. Dit wat in ander hoofstukke oor Abraham verhaal word en wat op die gebeure betrekking het, word daarom ook as egte gebeure gesien en nie as verwysings uit verskillende tradisies nie (Van Seters 2003:454-461), ook nie dat die laaste deel van Genesis 22 'n latere byvoeging is nie (Boehm 2004:155-156). ${ }^{2}$

1.In my artikel (Stoker 2014) wat handel oor die etiese bevraagtekening van God se opdrag, word onder andere ingegaan op die moontlike verklaring waarom God die opdrag, word onder andere ing gaan op die moontlke verklaning waarom God die opdrag gegee het - juls ook as 'n korrektief op die destydse Kanaanitiese praktyk van kinderoffers. Dit sluit aan by die gevolgtrekking waarby Kaiser (1983:269) uitkom aan die einde van sy hoofstuk wat oor die gebeure in Genesis 22 handel: 'God's character and the act he requires are fully consistend with everything tha both testaments would lead us to expect in our God.'

2.In die literatuur van die afgelope twee eeue is heelwat menings oor wanneer Genesis 22 geskryf is (vgl. Kaiser 2001:84-85), uit watter tradisie of tradisies, oor Genesis se moontlike samestelling, oor dele wat in die teks hoort en wat nie daar hoort nie, ensovoorts. Die rede vir hierdie debat lê onder andere in dit wat Crenshaw (2005:60) uitwys, naamlik dat in hierdie verhaal 'n balans voorkom tussen die gebruik van die name YHWH en Elohim vir God - elkeen word vyf keer gebruik. Die term vrees van die Here en die rol van die engel word gewoonlik aan die Elohis Die term vrees van die Here en die rol van dir engel word gewoonlik aan die Elohis toegeskryf, terwyl die klem op die belofte van die Here eerder op die Jahwis sou dui. Die artikel wil nie op hierdie debat of ander tekskritiese sake ingaan nie, maar wil sy doel bereik deur hierdie gedeelte te hanteer soos dit as historiese gebeure verhaa word. Dit sluit aan by die opmerking van Janzen (2011:182) as Ou-Testamentikus in reaksie op die standpunt van Siebert oor Abraham se optrede wanneer hy skryf: " can offer ... examples of some of the ways in which my mainly "canonical-literary" approach helped me to address passages and themes often found to be disturbing."
Die artikel gaan uit van 'die goue reël van gereformeerde Skrifuitleg' dat die Heilige Skrif sy eie verklaarder is, asook van die gepaardgaande vertrekpunt vir die etiek dat Skrifgedeeltes as tydgerig gesien word en nie as tydgebonde nie (Van Rooy 1997:7-8). Die artikel wil vrae beantwoord soos die volgende: Kan die optrede van Abraham as 'n geloofsdaad gesien word (Heb 11:17-19)?; Aangesien Abraham die vader van die gelowiges genoem word, beteken dit dat gelowiges sy voorbeeld moet volg en ook hulle kinders offer of doodmaak?

Om antwoorde op hierdie vrae te kry, word Genesis 22 anders as wat die bybelskritiese benadering sou doen en eerder in ooreenstemming met die kanoniese benadering (vgl. Barton 2007:38) - as historiese stof hanteer (soos dit in die Bybel staan), en evaluerend nagedink oor die reaksie van Abraham op die opdrag wat hy van die Here ontvang het. Hierdeur wil onder andere insig verkry word oor die mens se verhouding met God, waaruit die normatiewe vir gelowiges se lewe met mekaar bepaal word, asook 'n Christelike siening ten opsigte van die lewe en die dood. Dit word gedoen met die opmerking van Van Rooy (1997:1) in gedagte, naamlik dat in die behoorlike etiese nadenke oor gedeeltes van die Ou Testament, die spesifieke gedeeltes nie los van die groter verband van die Ou Testament gebruik mag word nie. Barton (2007:39) wys ook daarop dat in die kanoniese benadering 'the Bible will speak with a consistent voice on any given subject'. Nie alleen teoloë nie, maar ook die meeste gewone Christenlesers van die Bybel gaan van die vertrekpunt uit dat godsdienstige waarhede in enige gegewe deel van die Bybel nie in stryd sal wees met dit wat godsdienstig waar is in ander dele van die Bybel nie.

\section{Abraham se reaksie op die opdrag Offer van kinders is nie ' $n$ vreemde konsep nie}

Hoewel die doel van hierdie artikel nie is om op die gebruik van kinderoffers onder die antieke volke rondom die Middellandse see in te gaan nie, moet tog daarop gewys word dat kinderoffers reeds vanaf die antieke tyd 'n gebruik onder die Semitiese volke was (Rundin 2004:425-430; Stager \& Wolff 1984:32-38). Selfs in Israel was kinderoffers op 'n stadium die gebruik (vgl. Jer 7:30-32; 32:35; 2 Kon 17:16-17; 23:10). In Genesis 22 is daar ook geen aanduiding dat die opdrag tot die offer van sy kind vir Abraham 'n vreemde konsep was nie.

\section{Oënskynlik vreemde reaksie}

Abraham se reaksie is eintlik baie vreemd indien sy vroeëre optrede in ag geneem word. Uit sy vroeëre optrede blyk dat hy wel vir mense kon intree deur met God in 'n argumenterende gesprek te tree (Brueggemann \& Linafelt 2012:22, 24). 'n Mens lees boonop nie net in Genesis 19 hoe hy vir die lewe van die sondige mense van Sodom pleit nie, maar ook in Genesis 21 hoe hy begaan is oor die lot van sy seun Ismael wat van hom weggestuur word. Crenshaw (2005:223) wys daarop dat Abraham die morele regverdiging van God se beoordeling bevraagteken wanneer baie minder op die spel is - soos die 
oorlewing van twee stede waarvan die meeste vreemdelinge vir Abraham was. Wanneer hy egter in Genesis 22 die opdrag kry om sy ander seun te offer - die seun van die belofte op wie hy en Sara so lank gewag het (vgl. Gen 21:1-7) - lyk dit of hy sonder om dit te bevraagteken of vir sy seun in te tree en met God hieroor te worstel, die doodmaak van die seun bloot aanvaar. Hy staan vroeg op om dit te gaan doen (Tucker 1999:35), nadat hy waarskynlik die opdrag in die nag gekry het (Whitefield s.a.:3-4).

In vergelyking met die vorige hoofstukke waar Abraham se gesprek en intrede vir ander duidelik opgeteken is, lyk dit dus of hier van iets anders sprake is - dat hy iets weet of verstaan wat daartoe lei dat hy die opdrag gaan uitvoer sonder om met God daaroor te argumenteer. Wat dit is, het oor die jare verskillende verklarings ontlok. 'n Voorbeeld hiervan is Verderber $(2005: 290)$ in haar resensie van D.L. Miller se boek Dreams of the burning child. Sy verskil van Miller se siening dat die besluit van vaders om hulle kinders te offer (soos onder andere ook die geval met Abraham was), nie net gesien moet word teen die historiese konteks van 'n gegewe tyd en plek nie, maar ook teen die psigologiese agtergrond van die patriarg wat op hierdie manier die band wat hy met sy seun het, verewig. Sy (Verderber 2005:290 291) sluit aan by Freud se siening dat die westerse denke eerder op die opstand van die seuns teen vaders gebou is as op die doodmaak van die vaders deur die seuns. In hierdie gedeelte is daar egter geen aanduiding dat dit hier gaan oor 'n stryd tussen pa en seun nie. Dit blyk eerder dat daar goeie samewerking en onderlinge vertroue was.

Brueggemann en Linafelt (2012:22-23) wys op die geweldige impak wat die opdrag op Abraham moes gehad het. Al word daar nie na die innerlike emosionele reaksie van Abraham verwys nie, moes die opdrag om sy seun dood te maak groot emosionele spanning vir Abraham meegebring het. Ons lees wel dat God spesifiek na Abraham se liefde vir sy seun verwys (Gen 22:2). Die aanspreekvorm my seun (Gen 22:8), in plaas van die jongman (Gen 22:5), dui ook volgens Crenshaw (2005:62) op Abraham se toegeneentheid teenoor Isak.

Dat die opdrag van God aan Abraham sekerlik 'n botsing binne Abraham moes te weeg gebring het, is volgens Curzer (2002:244) tipies van morele dilemmas waar aksie, passie en perspektief binne-in 'n mens bots. Hy (Curzer 2002:231) beskryf hierdie soort dilemma as 'n botsing tussen die etiek van omgee en die etiek van geregtigheid. Wanneer dit in stryd met mekaar kom, kan die nakoming van die een ten koste van die ander, volgens hom, egter nie as 'n beter etiese keuse gesien word nie. Toegepas op die situasie van Abraham sou die nakoming van die opdrag volgens die etiek van geregtigheid as goed beskryf kan word (met die motivering dat God die lewe gee en die reg het om lewe te neem - Job 1:21), terwyl die nie-nakoming van God se opdrag ook as eties goed beskryf word, omdat dit aan die etiek van omgee voldoen. ('n Goeie pa sal tog doen wat hy kan om sy kind se lewe te beskerm en dit nie willens en wetens in die gevaar stel nie.) 'n Soortgelyke gebeurtenis waarna Curzer (2002:228-229) verwys, is dié van die Romeinse bevelvoerder Manlius, wat sy kind vir sy oortreding laat uitlewer het sodat hy die doodstraf daarvoor ontvang het. Sy seun sou sonder hierdie ingrype van sy pa met sy oortreding weggekom het. Deur sy seun uit te lewer, het hy aan die etiek van geregtigheid voldoen. Indien hy dit nie sou doen nie, het hy aan die etiek van omgee voldoen. Enige een van die optredes kan dus volgens Curzer as eties goed beskryf word. Volgens Curzer (2002:233) is dit vir Abraham 'n dilemma om tussen die etiese en die godsdienstige te besluit.

Die bekende filosoof Kierkegaard (1994:51) noem Abraham 'n tragiese held wat moes kies tussen die uitvoering van sy taak teenoor die oneindige (God) en sy taak teenoor die eindige (Isak).

Frame (2008:230-234) wys daarop dat wanneer 'n konflik tussen twee sake sou ontstaan (in die geval van Abraham tussen doodmaak en gehoorsaamheid), net een optrede reg kan wees. Wanneer daar 'n normkonflik in 'n situasie ontstaan, beteken dit steeds dat' $n$ mens eties reg moet optree. Al klink dit op die oog af of 'n mens die sesde gebod oortree indien jy byvoorbeeld uit selfverdediging of ter verdediging van ander mense iemand doodmaak, is dit iets wat 'n mens moet doen in 'n gegewe situasie en dit is dus nie oneties of 'n oortreding van die gebod nie.

Dieselfde geld ook vir die opdrag wat Abraham gekry het. Sy optrede - so anders as sy ander optrede - kan net verstaan word teen die agtergrond van God se belofte aan Abraham en sy gelowig vasgryp daaraan.

\section{Die belofte aan Abraham}

Vandat die Here Abraham geroep het om uit sy land te trek om in Kanaan 'n nuwe volk te begin (Gen 12), het die Here herhaaldelik aan hom beloof dat uit hom 'n groot nageslag sal voortkom. Die belofte was nie net 'n belofte aan hom nie, maar ook aan sy vrou Sara. Toe Abraham en Sara na baie jare nog nie 'n kind gekry het nie, het hulle saam besluit dat Abraham se nageslag deur Sara se slavin Hagar sou kom (Gen 16:1-2). Die Here het dit egter aan Abraham duidelik gemaak dat hy en Sara as getroude paar 'n seun sou hê. Hierdie seun van hulle sou die kind van die belofte wees uit wie 'n groot nageslag sou kom wat ook 'n seën vir die nasies sou wees (Gen 12:1-3; 17:19-21).

Dat die seun van die belofte wel Isak was, word ook deur die Here duidelik gemaak. In Genesis 17:19 sê God nog voor die geboorte van Isak al aan Abraham:

Nee, jou vrou Sara sal vir jou 'n seun in die wêreld bring. Jy moet hom Isak noem. Ek sal my verbond met hom hou as 'n blywende verbond, en ook met sy nageslag.

God sê ook aan Abraham dat hoewel Ismael 'n groot en sterk nageslag sou hê, hy nie die seun van die verbond is nie: 'Maar dit is met Isak, die seun wat Sara vir jou oor 'n jaar in die wêreld sal bring, dat Ek my verbond sal nakom' (Gen 17:21). 
Hagar en Ismael word dan weggestuur. Isak word daardeur die enigste kind wat by Abraham oor is - die een deur wie die seën en beloftes in vervulling moet gaan.

Dit is juis na hierdie situasie van Isak, naamlik die enigste kind deur wie die beloftes van die Here in vervulling moet gaan, waarna God verwys as Hy die opdrag aan Abraham gee om hierdie kind te gaan offer. In die lig van alles wat met hom en sy gesin gebeur het, sou Abraham baie goed begryp het wat God sê as Hy in sy opdrag in Genesis 22:2 na Isak met die volgende woorde verwys: 'Vat jou seun, jou enigste seun, Isak, wat jy liefhet ...'. Die Here kon net vir hom gesê het om vir Isak te vat en hy sou geweet het na wie die Here verwys. Deur die beskrywing van wie Isak is, bring Hy Abraham egter weer terug by die belofte wat Hy aan hom en Sara gemaak het (Paul et al. 2011:213). Met reg merk Barton (2002:21-22) op dat die spesifieke detail wat in Ou-Testamentiese verhale gegee word van kardinale belang is vir die verstaan van daardie gedeelte.

Dat Abraham nie die verwysing na Isak as sy enigste seun, die een wat hy liefhet, as negatief beskou het nie, blyk uit sy optrede. Hy het so gou moontlik (vroeg die volgende more, nadat God waarskynlik die vorige aand met hom gepraat het) aan die opdrag gehoor gegee. Dit blyk verder uit die positiewe antwoord wat hy Isak gee op sy navraag oor die offerlam, naamlik: 'My seun, God sal sy eie offerlam voorsien' (Gen 22:8). ${ }^{3}$ Sy woorde en optrede wys nie op opstandigheid nie, maar op gewilligheid en die sekerheid van God se voorsiening. Hy wat eers gelag het oor die idee dat hy en Sara in hulle ouderdom 'n kind sou kry (Gen 17:17), net soos Sara (Gen 18:10-18) ook gelag het, het nou gelowig aan die belofte van die Here vasgegryp. Hy het die Here vertrou - Hy Wie hierdie kind so laat in sy lewe aan hom gegee het en met Wie hy so 'n spesiale verhouding kon opbou (Kaiser 1988:50-51). Vir die Here is niks te buitengewoon om te doen nie (Gen 18:14).

\section{Gelowige vasgryp aan die belofte}

Abraham se geloof lê nie daarin dat hy gelowig gaan om sy kind te offer nie. Sy geloof lê daarin dat hy geglo het dat God sy belofte sal uitvoer - selfs deur die dood van hierdie kind heen. God het aan hom en Sara 'n seun gegee toe dit onmoontlik was om 'n kind te kry. God sal deur hierdie kind van die belofte, Isak, aan hom en Sara 'n nageslag gee, selfs deur die dood heen - al lyk 'n opstanding uit die dood menslik onmoontlik.

Was dit dus eties goed van Abraham om hierdie opdrag van die Here uit te voer? Kierkegaard (1994:51) stel dat Abraham in sy gehoorsaamheid aan God kies vir die godsdienstige teen die etiese. Hy kom nie sy etiese verantwoordelikheid na nie en oortree daarmee basiese morele standaarde ter wille van sy geloofsposisie. Tucker (1999:43) se siening kom met Kierkegaard ooreen wanneer hy stel dat Abraham se godsdienstige keuse vir kindermoord eties immoreel is.

3.Brueggemann en Linafelt (2012:23) wys daarop dat die sin ironies genoeg ook kan lees God sal sy eie offerlam voorsien, naamlik my seun.
Die keuse waar Abraham voor te staan gekom het, hoef egter nie as 'n keuse tussen die godsdienstige en die etiese eise gesien te word nie. Die teendeel blyk eerder waar te wees indien hierdie gedeelte in die lig van die NuweTestamentiese verklaring daarvan in Hebreërs 11 gelees word. Laasgenoemde hoofstuk gaan van die vertrekpunt uit dat om te glo beteken 'om seker te wees van die dinge wat ons hoop, om oortuig te wees van die dinge wat ons nie sien nie'. Abraham se optrede in Genesis 22 is een van die voorbeelde van sodanige geloof wat Hebreërs 11 voorhou. Uit Hebreërs 11:17-19 is dit duidelik dat Abraham in sy geloof in God en God se belofte dat sy beloofde nageslag uit Isak gebore sou word, gegaan het om vir Isak te offer:

Omdat Abraham geglo het, het hy, toe hy op die proef gestel is, Isak as offer afgestaan. Ja, hy wat die belofte ontvang het en aan wie gesê is: 'Uit Isak sal jou nageslag gebore word,' het gereed gestaan om sy enigste seun te offer. Hy was daarvan oortuig dat God by magte is om uit die dood op te wek, waaruit Abraham vir Isak ook, om dit so te stel, terug ontvang het.

Uit die manier waarop God na Isak verwys in die opdrag om hom te gaan offer, moes Abraham besef het dat dit 'n toets is vir sy vertroue in die belofte en almag van God - 'n geloofstoets. Hebreërs 11 begin daarom die weergawe van hierdie geskiedenis met die woorde 'Omdat Abraham geglo het ...'. Hy het gelowig op God vertrou vir 'n wonderlike uitkoms vir hom, Sara, Isak en die nageslag wat uit Isak sou voortkom om uiteindelik 'n seën vir die nasies te wees. Dat Isak self aan hierdie belofte moes gedink en vasgehou het, blyk daaruit dat hy as 'n jongman (waarskynlik 20 jaar of ouer - Miller 2003:1), sy bejaarde pa (van ver oor die 100 jaar oud - Gen 21:5) toegelaat het om hom vas te bind om hom te offer. Wenham (1994:109) stem met hierdie siening saam en wys daarop dat dit makliker vir die bejaarde Abraham sou gewees het om, wanneer Isak dit nie verwag het nie, hom keel af te sny (soos dit wel by brandoffers in Levitikus gedoen is), as om 'n jong man teen sy sin vas te bind - een wat self die hout teen die berg kon opdra soos Mathews (2005:289) in ooreenstemming hiermee opmerk. Dit kon selfs gewees het dat Isak wou hê dat hy vasgebind word, sodat hy nie op die laaste oomblik sou probeer wegruk en die offer onwaardig sou maak nie (Crenshaw 2005:64). Die omstandigheid wat geskets word, bring 'n mens by die feit dat sowel Abraham as Isak in hierdie verskriklike omstandighede aan die belofte van God vasgehou het, naamlik dat uit Isak 'n groot nageslag sou kom.

In hierdie opsig is dit ook belangrik om te sien hoe hierdie opdrag direk by die eerste opdrag aansluit wat Abraham van God ontvang het en waarop hy ook geloofsvertrouend moes reageer:

Die eerste opdrag van God aan Abraham (Gen 12:1-2) was die volgende:

- Gaan-gaan (lek-leka) na die beloofde land.

- Gaan na die land ('el-'ereset) wat Ek jou sal wys.

- Die belofte het saam met die opdrag gekom: 'Ek sal jou 'n groot nasie maak'. 
Die laaste opdrag van God aan Abraham (Gen 22:2) het soos volg gelui:

- Gaan-gaan (lek-leka) na Moriaberg (Gen 22:2).

- Gaan na die landstreek ('el-ha'areset) van Moria.

- Isak, die seun deur wie die belofte van 'n groot nasie vervul sou word, is deel van die geloofsopdrag.

Volgens Crenshaw (2005:62-63) moes Abraham die twee opdragte bymekaar uitgebring het deur die herhaling van die drievoudige opdrag deur die bekende stem van God, asook die feit dat die uiteindelike plek waarheen hy gestuur word nie presies beskryf word nie, maar dat dit slegs vermeld is dat dit 'n plek is wat God hom sal aanwys, asook die belofte dat die Here (uit Isak) vir hom 'n groot nageslag sou gee. Albei opdragte het 'n geweldige vertroue in God van die kant van Abraham vereis. Dat sowel die opdragte as die belofte by mekaar aansluit, blyk ook daaruit dat die Here dit wat Hy by die eerste opdrag in die begin sê, na die afhandeling van die laaste opdrag aan Abraham bevestig, naamlik dat Hy hom 'n groot nageslag sal gee (Gen 12:2; 22:17).

Abraham was nie net bereid om uit geloof sy verlede op te offer nie (trek uit jou land), maar ook om sy toekoms op die spel te plaas (offer vir Isak). Dit het hy gedoen op grond van God se belofte dat uit hom, deur Isak, 'n nageslag sal kom wat tot seën van die nasies sal wees.

\section{Abraham se optrede geweeg}

Lewe en liefde speel 'n kardinale rol in die lewe van bybelse gelowiges. Johannes 3:16 sê dat God ons so lief gehad het dat Hy sy Seun gegee het, sodat ons kan lewe. Saam met lewe en liefde gaan gehoorsaamheid. 1 Johannes 5:2 stel 'Hieraan weet ons dat ons die kinders van God liefhet: wanneer ons God liefhet en sy gebooie onderhou.' Om nie in moralisme te verval nie, moet Abraham se optrede verder gesien word as deel van sy vrees of eerbied vir God. Sy nakoming van die opdrag word vervolgens gemeet aan die aspekte van lewe, liefde en gehoorsaamheid, wat uit sy ontsag vir God voortgevloei het.

\section{Lewe}

In die Bybel en die Christelike etiek is die beskerming van lewe een van die belangrikste oorwegings wanneer besluite gemaak moet word. In sy deeglike uiteensetting van die Christelike etiek stel Frame (2008):

we must respect life as an aspect of our reverence for God. We should especially respect human life because it is the image of God, that image that grounds the first prohibition of bloodshed in Scripture (Gen 9:5-6). (p. 685)

Indien lewe in etiese besluitneming dan so belangrik is, kom die vraag of Abraham nie op grond hiervan moes geweier het om die opdrag uit te voer om sy seun te offer nie. Wanneer daar oor Ragab se geloof in Hebreërs 11 gehandel word, word haar optrede, wat 'n leuen insluit ter wille van die beskerming van die lewe van die verspieders, juis as 'n voorbeeld van gehoorsaamheid aan God voorgehou (Heb
11:31): 'Omdat Ragab, die prostituut, geglo het, het sy die verkenners vriendelik ontvang en het sy nie omgekom saam met dié wat aan God ongehoorsaam was nie.' Dit is egter nie 'n geval dat die Bybel oneerlikheid goedpraat nie. God is die God van die waarheid wat leuens haat (Eks 20:16; Joh 14:6; Op 22:15). Dit is egter wel so dat die lewe van jou naaste voorrang moet geniet. Daarom kon die twee vroedvroue, Sifra en Puah, met reg oneerlik teenoor die Farao gewees het, om die lewe van die babaseuntjies te kon red (Eks 1:15-21). 1 Samuel 19 en 20 verhaal van die oneerlikheid van Jonatan teenoor sy pa ter wille van die lewe van sy vriend Dawid (Geisler \& Snuffer 2007:58).

In die etiese beoordeling van Abraham se gehoorsame bereidheid om die lewe van sy seun te neem, wys Paul Copan (2011:50) daarop dat die doodmaak van 'n mens verkeerd is omdat jy iemand die lewe ontneem. Volgens hierdie definisie sou 'n mens dus kon doodmaak indien dit moontlik was om daardeur die persoon se lewe nie weg te neem nie, dit wil sê indien die persoon sou kon herlewe.

Ons siening dat dit verkeerd is om ' $\mathrm{n}$ mens dood te maak, berus op die wete dat iemand nie uit die dood kan terugkom nie. Abraham het egter geglo, op grond van die belofte van die Here aan hom, dat Isak nie sou dood bly nie. Wanneer hulle naby Moriaberg kom, sê hy vir sy dienaars in Genesis 22:5 om op hulle te wag. Hy stel pertinent die vertroue dat hy en Isak na hulle sal terugkeer: 'Wag hier met die donkie. Ek en die seun gaan daar aanbid, dan kom ons terug na julle toe.' Indien hierdie verse nie in die lig van die lewewekkende krag van God verstaan word nie, sou dit Abraham se woorde en optrede immoreel kon maak. Dit is waarby Tucker (1999:35) uitkom wanneer hy sê: 'Abraham's lie is an explicit recognition of the immoral nature of the sacrifice'.

Hebreërs 11:17-19 stel pertinent dat Abraham op grond van die belofte van God daarvan oortuig was 'dat God by magte is om uit die dood op te wek' en dat hy Isak uit die dood sou 'terug ontvang'. Sonder God se direkte opdrag sou Abraham se optrede teenoor sy kind moord gewees het. Saam met die opdrag kom die vertroue dat God wel nog sy beloftes sal uitvoer in en deur die lewe van Isak. Dus kon Abraham in gehoorsaamheid ook hierdie opdrag ten uitvoer bring (Copan 2011:50).

\section{Liefde}

Van die begin van die opdrag aan Abraham in Genesis 22 tot by die ontknoping op die berg bly dit 'n vraag vir die leser hoe die gebod van die liefde vir jou naaste te rym is met Abraham se optrede. In hulle boek oor Christelike etiek stel Geisler en Snuffer (2007:30) 'Love is the proper motivation for all moral choices'. Die Here Jesus vat die wet, wat as etiese kode in die Judese en Christelike wêreld dien, saam met die opdrag 'Jy moet die Here jou God liefhê met jou hele hart ... en jou naaste soos jouself'. Romeine 13:8-10 brei hierop uit wanneer dit stel:

Julle moet niemand iets verskuldig wees nie, behalwe om mekaar lief te hê. Wie sy medemens liefhet, voer die hele wet 
van God uit. ... Die liefde doen die naaste geen kwaad aan nie. Daarom is die liefde die volle uitvoering van die wet.

Die vraag kan dus gevra word of Abraham uit liefde teenoor sy naaste, Isak en Sara, gehandel het deur te gaan om vir Isak te offer. Die vraag kan ook omgekeerd gevra word, naamlik of daar liefde vir God en die naaste sonder gehoorsaamheid aan God kan wees.

Hoewel die fokus in Genesis en Hebreërs op Abraham se geloof val, is dit duidelik dat Sara en Isak nie daarvan uitgesluit was nie. Nie net is Abram se naam na Abraham verander om aan te dui dat hy die vader van baie nasies sou wees nie (Gen 17:4-6), maar Sarai se naam is deur God self verander na Sara om haar betrokkenheid in die belofte te beklemtoon (Gen 17:15-16). Soos reeds aangetoon (vgl. 'Gelowige vasgryp aan die belofte') het Abraham Isak nie ewe skielik oorval nie, maar het Isak hom laat vasbind. Dit dui ook op 'n gelowige buig voor God se bevel (Crenshaw 2005:64).

\section{Gehoorsaamheid}

Uit die lees van Genesis 22 as 'n historiese verhaal, asook die latere verwysing hierna in Hebreërs 11, is dit duidelik dat dit in hierdie verhaal oor Abraham se geloofsgehoorsaamheid aan God gaan. Paul et al. (2011:213) wys daarop dat Abraham drie keer in die verhaal sê 'Hier is ek' (Gen 22:1, 7, 11), wat impliseer dat hy hom ter beskikking stel van dit wat God van hom vra (vgl. Jes 6:8). Mathews (2005:291) sien dit as die bewys van Abraham se oorgegewe gehoorsaamheid aan God dat hy vroeg die volgende dag vertrek het om hierdie opdrag uit te voer (Gen 22:3).

Boehm (2004) wil die verhaal in Genesis 22 nie as 'n polemiek teen kinderoffers sien nie, maar wil dit, in weerwil van wat die verhaal self aandui, sien as Abraham wat eties vasstaan en in ongehoorsaamheid aan God nie die offer van Isak laat plaasvind nie:

While in the myth of child sacrifice the people is perserved because the readiness of its leader to slay his son, in this story it is perserved because of his refusal to do so. (p. 156)

Volgens hierdie siening van Boehm was Abraham ongehoorsaam aan God om nie die offer uit te voer nie, maar het hy dit op goeie etiese gronde geweier - soos ook gesien kan word in sy weiering om die aanbod van Sodom se koning te aanvaar (Gen 15:21-23). Deur die ram in die plek van Isak te offer (Gen 22:13) was Abraham, volgens Boehm (2004:155), ongehoorsaam aan God se bevel. Hy sien dit as 'n latere invoeging dat God sy bevel gewysig het sodat die ram geoffer moes word. Boehm (2004:156) stel dat anders as die ander verhale van kinderoffers in die Nabye-Ooste, Israel nie gespaar word as gevolg van die offer van die seun nie, maar deur die oorlewing van die seun wanneer die pa sy etiese verantwoordelikheid nakom.

Boehm se siening is egter onhoudbaar indien Genesis 22 gelees word soos wat dit daar staan. Ter wille van die etiese dat 'n pa nie sy kind kan gaan doodmaak nie, stel Boehm dat Abraham geweier het om dit te doen - direk in stryd met wat die teks self sê. Behalwe dat daar nie enige aanduiding bestaan dat sy siening reg kan wees nie, is dit ook nie noodwendig dat Abraham bloot eties kon optree deur ongehoorsaam te wees nie. Dit blyk uit die volgende twee punte.

Die gebeure met Ismael in die hoofstuk vóór Genesis 22 was volgens Copan (2011:46-47) 'n vooraftoets vir die gebeure met Isak. Toe Isak gespeen is, het Ismael hom gespot (Gen 21:9). Abraham is lief vir Ismael en wil hom nie die woestyn in wegstuur soos Sara wil hê moet gebeur nie (Gen 21:11). Hy doen dit egter tog in gehoorsaamheid aan God en in die vertroue op sy belofte dat Ismael sal oorleef en 'n groot nasie sal word (Gen 21:12-13; 17:20). Sonder hierdie belofte sou dit verkeerd gewees het van Abraham om Ismael weg te stuur na 'n waarskynlike dood in die woestyn.

Na die moeilike opdrag met betrekking tot Ismael, waar Abraham in gehoorsaamheid aan God se belofte moes vashou, kry hy in die volgende hoofstuk die opdrag om Isak te offer. God beklemtoon in hierdie opdrag dat Isak nou Abraham se enigste seun is (Gen 22:2) - die seun van die belofte; die belofte aan Abraham van 'n groot (en besondere - Gen 12:1-3) nageslag uit Isak. Copan (2011:47) wys daarop dat Abraham se gehoorsaamheid om Isak te gaan offer, gesien moet word in die konteks van sy geloofsvertroue dat God sy beloftes hou soos getoon is in die wondergeboorte van Isak, asook sy beskerming van Ismael.

\section{Ontsag}

Die uitvoering van die opdrag om Isak te gaan offer, dui vir Murray (1957:139-140) daarop dat Abraham in groot ontsag vir God optree. Hierdie ontsag kan al gesien word wanneer Abraham (wat die senior vennoot is), vir Lot die eerste keuse gee op 'n landstreek om in te bly (Gen 13:8-12). Hy kon dit uit ontsag vir God doen. Dit het voortgevloei uit sy vertroue op God se belofte en voorsienigheid. Hierdie ontsag vir God blyk ook uit sy hantering van die weiering van die finansiële aanbod van die koning van Sodom (Gen. 14:22-23). In plaas van selfgerigtheid spreek hierdie optrede van ontsag en godgerigtheid. Tot vandag toe is ontsag vir God vir Murray die antwoord op skynvroomheid onder Christene.

Die ontsag vir God as 'n rede vir Abraham se optrede blyk uit verskeie aspekte van die verhaal van Genesis 22. Terwyl Abraham met God op ander tye worstel (op 'n wyse wat van groot ontsag spreek - vgl. Gen 18:23-33), is hier geen teken van ' $n$ worsteling oor die opdrag van die Here nie. Hoewel Isak letterlik die toekoms is waarvoor Abraham so lank gewag het, maak hy die volgende dag vroeg klaar om dit wat God van hom verwag, so gou moontlik uit te voer. In sy gesprekke met die diensknegte en sy seun is daar ook geen teken van vertwyfeling of verwyt teenoor God nie - net geloofsvertroue en ontsag: 'Ek en die seun gaan daar aanbid, dan kom ons terug na julle toe' (Gen 22:5b) en 'My seun, God sal sy eie offerlam voorsien' (Gen 22:8b). Kennis en ontsag vir God verduidelik waarom Abraham opgetree het soos dit in Genesis 22 beskryf is (vgl. Spr 1:7). 
Ontsag, spesifiek die ontsag vir God, raak die diepste motivering vir die optrede van 'n gelowige en juis ook vir Abraham, die vader van al die gelowiges (Gal 3:7, 29). Daaruit spruit die wil om tot eer van God en tot die goeie voordeel van ander te lewe (vgl. Deut 6:24; 10:13). Frame (2008:50) noem hierdie die teleologiese beginsel, aangesien dit stel dat die mens se gedrag gefokus moet wees op die doel, naamlik dat dit God moet eer, asook goed moet doen aan mense, jouself ingesluit.

In Wright (2004:59) se bespreking van die Ou-Testamentiese teologiese dimensie wat vir die Ou-Testamentiese etiek belangrik is, wys hy daarop dat Israel nie bloot net ontstaan het nie, maar dat die volk van God op grond van God se belofte aan Abraham ontstaan het. In hierdie belofte lê ook God se bedoeling, naamlik om 'n seën vir al die nasies te bring - deur Abraham se nageslag via Isak. Die Here openbaar Hom van die begin af as die doelgerigte God. Abraham het die sekerheid gehad dat nie net hy nie, maar ook Isak, deel van hierdie doel is.

Hierby kan ook die deontologiese beginsel geplaas word, naamlik dat die mens sy taak - dit wat hy behoort te doen moet uitvoer, al het dit moeilike of selfs slegte konsekwensies vir homself. Frame (2008:50) verwys byvoorbeeld spesifiek na die optrede van Abraham. Hy het sy grond en familie gelos om in ' $n$ vreemde land as vreemdeling te gaan woon in opdrag van God (Gen 12); hy het ook sy seun Isak teen die berg Moria uitneem om God se opdrag te gehoorsaam, naamlik om hom te gaan offer (Gen 22).

Die derde etiese beginsel wat Frame (2008:50-51) uitlig, die eksistensiële beginsel, sluit in die lewe van die Christen ten nouste aan by sy ontsag vir God. Hierdie beginsel in die etiek vra na die motivering wat 'n persoon laat optree soos hy optree. Die Here Jesus wys die fariseërs daarop dat dit nie help dat hulle optrede van buite af goed lyk nie, maar dat hulle van binne vuil is - soos 'n beker of skottel wat net buite gewas is (Matt 23:25). Filippense 2:12-13 bring ook die Christen se ontsag vir God uit by sy gehoorsaamheid, gewilligheid en vermoë om God se wil uit te voer:

My geliefdes, julle was altyd gehoorsaam wanneer ek by julle was. Des te meer moet julle gehoorsaam wees nou dat ek nie daar is nie. Julle moet julle met eerbied en ontsag daarop toelê om as verloste mense te lewe, want dit is God wat julle gewillig en bekwaam maak om sy wil uit te voer.

Met ontsag vir God kon Abraham in gehoorsaamheid gaan om te doen wat God van hom gevra het. Sy eerbied en ontsag vir God het hom, in die woorde van Filippense 2:12-13, gewillig en bekwaam gemaak om gehoorsaam te wees, al het dit van hom deontologies geweldig baie gevra om hierdie taak te gaan uitvoer. Om hierdie rede regverdig Hebreërs 11 nie net Abraham se optrede eties nie, maar hou dit ook voor as 'n voorbeeld van wat dit beteken om te glo.

\section{Die motief, doel, wyse en gevolg van Abraham se optrede}

'n Handige wyse om Abraham se handelswyse in Genesis 22 eties samevattend te ontleed, is om nader te let op die motief, die doel, die wyse en die gevolg (vgl. Stoker 1983:91-103) van Abraham se optrede.

Die motief kan verdeel word in die beweegrede en die dryfveer (Stoker 1983:91-97). Dit is reeds uitgewys (vgl. 'Gehoorsaamheid') dat Abraham daarop ingestel was om God te gehoorsaam en dat dit hom beweeg het om die opdrag van God uit te voer. Die dryfveer was sy ontsag en liefde vir die Here. Uit die oogpunt van 'n Christengelowige kan die motief vir Abraham se optrede dus as eties goed beoordeel word.

Teenoor sonde, wat beskryf kan word as om jou doel te mis, was Abraham se doel om dit wat God van hom verwag, te doen. Hebreërs 11:17-18a begrond hierdie doel van sy geloof soos volg: 'Omdat Abraham geglo het, het hy, toe hy op die proef gestel is, Isak as offer afgestaan.' 'n Gelowige kan dus die doel van Abraham se optrede positief beoordeel.

Die etiese bevraagtekening van Abraham se optrede trek ongetwyfeld saam in die wyse van sy optrede, naamlik dat hy gaan om vir Isak te offer. In die etiese beoordeling geld die spreekwoord die doel heilig nie die middel nie. Goeie bedoelings maak verkeerde optrede verstaanbaar, maar nie goed, reg of aanvaarbaar nie. Dat uit die Skrif aangetoon kan word dat Abraham op grond van die regte redes gehandel het, maak nog nie sy optrede self goed nie. Selfs die gedagte dat dit hier om noodetiek gaan, waar hy die minste kwaad moes kies tussen ongehoorsaamheid aan God en die doodmaak van sy seun, kan nie hier uitkoms bied nie, aangesien dit God in die beskuldigdebank sou plaas. Hy gee naamlik 'n opdrag wat direk teen sy eie wil ingaan.

Soos reeds bespreek, het Abraham vasgegryp aan die belofte van God dat daar uit Isak vir hom 'n groot nageslag gebore sou word. 'Hy was daarvan oortuig dat God by magte is om uit die dood op te wek, waaruit Abraham vir Isak ook, om dit so te stel, terug ontvang het' (Heb 11:19). Copan (2011:50) wys daarop dat doodmaak verkeerd is omdat iemand se lewe geneem word. As iemand se lewe nie geneem word nie, hoef dit egter nie verkeerd te wees nie. Dit kan selfs goed wees. Hy stel die voorbeeld dat indien dit nodig sou wees dat mense op 18-jarige ouderdom doodgemaak moes word, omdat dit al manier was hoe hulle kon oorleef en van die tienerstadium tot volwassenheid kon ontwikkel, die doodmaak van 18-jariges selfs goedgepraat kon word. Dan sou die doodmaak as eties goed beskryf kon word, terwyl die weiering om dood te maak as eties sleg beskryf kan word, omdat 'n persoon daardeur van sy volwassenheid ontneem kon word. Soos Abraham het Isak ook geweet dat dit ' $n$ wonderwerk van God was dat hy gebore is en dat dit nou ook 'n wonderwerk sal kos om hom ná die offer te laat opstaan, sodat uit hom die beloofde nageslag kon kom. Hy en Abraham sou saam terugkeer van die berg af (Gen 22:5). Die wyse van Abraham se optrede kan hiervolgens as 'n geloofshandeling en die suksesvolle aflegging van 'n toets (Heb 11:19) beoordeel word - dus eties goed. 
Die gevolg van Abraham se optrede kan ook as eties goed beoordeel word. Nie net het dit 'n groot nageslag vir Abraham uit Isak beteken nie (Gen 22:16-17), maar dit het ook tot gevolg gehad dat al die nasies van die aarde uit Abraham se nageslag God se seën ontvang (Gen 22:18; Matt 28:19) - die Messias is uit hierdie nageslag gebore.

\section{Ten slotte}

Wanneer hy Abraham se optrede in Genesis 22 bespreek, merk Yonder (1971:94) op dat dit nie van nut is om vroeëre etiese dokumente aan latere etiese standaarde te meet nie. In plaas van om optredes te meet aan latere situasies, moet dit volgens hom eerder gemeet word aan dit wat vooraf gebeur het of in daardie tyd die heersende tendense was. In hierdie sin is dit moontlik om die gebeure en die afloop daarvan as 'n korrektief te sien op die heersende idee van kinderoffers onder die Kananiete in wie se land Abraham gebly het.

Dat die heersende situasie, wat juis ook die belofte van God aan Abraham ten opsigte van Isak insluit, belangrik is vir die verstaan van die gebeure, is deurlopend in die artikel uitgewerk. Die spesifieke belofte wat God herhaaldelik aan Abraham gemaak het ten opsigte van Isak, gee insig in die optrede van Abraham. Dit gee egter ook die perspektief dat hierdie gebeure 'n eenmalige karakter het en nie as normatief of as ' $n$ etiese standaard vir die doodmaak van kinders (of enige mens), gebore of ongebore, gesien kan word nie.

Abraham se optrede kan in sy spesifieke omstandighede en op grond van dit wat in die artikel beredeneer word, as eties regverdigbaar gesien word. Daar hoef dus nie gepoog te word om uit 'n etiese dilemma te kom deur die historisiteit of gesagvolheid van Genesis 22 of 'n deel daarvan te bevraagteken nie. Die optrede van Abraham soos dit in Genesis 22 verhaal word, hoef nie as immoreel en as 'n optrede wat teen 'n Christelike etiek indruis, gesien te word nie. Om dit as normatief vir die doodmaak van kinders (of enige mens), gebore of ongebore, voor te hou, sal in stryd wees met die gebeure self ('n ram in die plek van Isak) en 'n verdraaiing van die res van die Skrif.

\section{Erkenning \\ Mededingende belange}

Die outeur verklaar dat hy geen finansiële of persoonlike verbintenis het met enige party wat hom nadelig kon beïnvloed het in die skryf van hierdie artikel nie.

\section{Literatuurverwysings}

Barton, J., 2002, Ethics and the Old Testament, SCM, London.

Barton, J., 2007, The Old Testament: Canon, literature and theology-Collected essays of John Barton, Ashgate, Hampshire.

Boehm, O., 2004, 'Child sacrifice, ethical responsibility and the existence of the people of Israel', Vetus Testamentum 54(2), 145-156. http://dx.doi. org/10.1163/156853304323018855

Brueggemann, W. \& Linafelt, T., 2012, An introduction to the Old Testament: The canon and Christian imagination, Westminster John Knox Press, Louisville.

Copan, P., 2011, Is God a moral monster?, Baker Books, Grand Rapids.

Crenshaw, J.L., 2005, Defending God: Biblical responses to the problem of evil, Oxford University Press, New York. http://dx.doi.org/10.1093/0195140028.001.0001

Curzer, H.J., 2002, 'Admirable immorality, dirty hands, care ethics, justice ethics, and child sacrifice'. Ratio, pp. 227-244. http://dx.doi.org/10.1111/1467-9329.00188

Frame, J.M., 2008, The doctrine of the Christian life, P\&R Publishing, Phillipsburg.

Geisler, N.L. \& Snuffer, R.P., 2007, Love your neighbour, Crossway Books, Wheaton.

Janzen, W., 2011, Teaching the Old Testament: The 'problem' of the Old Testament revisited, viewed 06 January 2014, from http://www.directionjournal.org/40/2/ teaching-old-testament-problem-of-old.html

Kaiser, W.C., 1983, Toward Old Testament ethics, Academie Books, Grand Rapids.

Kaiser, W.C., 1988, Hard sayings of the Old Testament, InterVarsity, Downers Grove.

Kaiser, W.C., 2001, The Old Testament documents: Are they reliable and relevant?, InterVarsity, Downers Grove.

Kierkegaard, S., 1994, Fear and trembling, Everyman's library, London.

Mathews, K.A., 2005, The new American commentary, Genesis 11:27-50:26, vol. 1B, Broadman \& Holman, Nashville.

Miller, D.L., 2003, How old was Isaac when Abraham was told to offer him? viewed 14 June 2012, from http://www.apologeticspress.org/APContent aspx?category $=11$ \&article $=1272$

Murray, J., 1957, Principles of conduct, Eerdmans, Grand Rapids.

Paul, M.J., Van den Brink, G. \& Bette, J.C., 2011, Bijbelcommentaar Genesis-Exodus, Centrum voor Bijbelonderzoek, Veenendaal.

Rundin, J.S., 2004, 'Pozo Moro, child sacrifice, and the Greek legendary tradition', Journal of Biblical Literature 123(3), 425-447. http://dx.doi.org/10.2307/3268041

Simms, N., 2000, 'The unspeakable agony of Kiddusth Ha-shem: Forced Jewish infanticide during the First and Second Crusades', The Medieval History Journal 3(2), 337-362. http://dx.doi.org/10.1177/097194580000300207

Siebert, E., 2009, Disturbing divine behavior: Troubling Old Testament images of God, Fortress, Minneapolis.

Stager, L.E. \& Wolff, S.R., 1984, 'Child sacrifice at Cartage - Religious rite or population control?', Biblical Archaeology Review 10(1), 30-51.

Stoker, H.G., 1983, Die vraagstuk van deontologie in die filosofie van HG Stoker, PU vir $\mathrm{CHO}$, Potchefstroom

Stoker, H.G., 2014?, 'God se opdrag aan Abraham om sy kind te offer: Eties bekyk', Ongepubliseer.

Tucker, A., 1999, 'Sins of our fathers: A short history of religious child sacrifice', Zeitschrift für Religions- und Geistesgeschichte 51(1), 30-47. http://dx.doi. org/10.1163/157007399X00045

Van Rooy, H.F., 1997, 'Etiek en Ou Testament: 'n Kritiese bespreking van bybelse grondslae vir moderne etiese vraagstukke', In die Skriflig 31(1 \& 2), 1-17.

Van Seters, J., 2003, 'From child sacrifice to Paschal lamb: A remarkable transformation in Israelite religion', Old Testament Essays 16(2), 453-463.

Verderber, S., 2005, 'Review of David Miller's book "Dreams of the burning child: Sacrificial son and the father's witness"', Shakespeare Studies 32(1), 289-294.

Wenham, G.J., 1994, Word biblical commentary: Genesis 16-50, Word Books, Dallas.

Whitefield, G., s.a., Abraham's offering up his son Issac, viewed 14 June 2012, from http://www.reformed.org/documents/index.html?mainframe=/documents/ Whitefield/WITF_003.html

Wright, C.J.H., 2004, Old Testament ethics for the people of God, InterVarsity, Leicester.

Yonder, J.H., 1971, The original revolution: Essays on Christian pacifism, Herald, Scottdale.

Young, E.J., 1964, Studies in Genesis one, P\&R Publishing, Phillipsburg. 